\title{
The Phillips Curve in Italy
}

\author{
Agostinho Silvestre Rosa \\ Universidade de Évora (PORTUGAL) \\ Endereço para contato Departamento de Economia, Universidade de Évora, Largo dos Colegiais 2 - Évora - \\ Portugal. Telephone: (351) 266740 894, Fax: (351) 266742494. \\ CEP: 7000-803 - E-mail: arosa@uevora.pt
}

Recebido em 30 de agosto de 2014. Aceito em 18 de dezembro de 2014.

\begin{abstract}
The estimation of the Phillips curve in Italy, using the wage inflation rate as a dependent variable, based on annual data from the period 1961-2012, using the Johansen Method, allows us to conclude two things. Firstly, in the long term, there are two long-term relationships: the wage inflation rate relates positively to the inflation rate, negatively to the unemployment rate and positively to the average labour productivity growth index, as was expected; the inflation rate relates positively to the wage inflation rate, negatively to the unemployment rate and positively to the average labour productivity growth index, as was expected. Secondly, in the short term, the variation of the wage inflation rate relates positively and significantly to the error correction mechanism of the first long-term relationship; therefore, there is a significant response to the equilibrium error between the wage inflation rate and its determinants (inflation rate, unemployment rate, labour productivity growth index). Besides this adjustment, the variation of wage inflation rate responds significantly and negatively to the variation in unemployment rate and significantly and positively to the average labour productivity growth.
\end{abstract}

JEL Classification: C12, C32, E24, E31

Key Words: Wage Inflation, Phillips curve, Cointegration 


\section{Introduction}

The original Phillips curve describes an empirical relationship between wage inflation and unemployment in accordance with Phillips (1958). Lipsey (1960) introduces the theoretical fundaments of that curve and Samuelson and Solow (1960) apply the more used modification: the relation between the inflation rate and the unemployment rate. This relationship was greatly used in the $1960 \mathrm{~s}$ by policy-makers. The trade-off between inflation and unemployment was recommended to economic policy makers as an instrument that would allow them to formulate policy programmes with alternative combinations of unemployment and inflation rate.

The Oil Shock in the 1970s raised problems in relation to that theory, because there was unemployment together with increasing inflation. Friedman (1968) and Phelps (1967) introduced expectations in the original Phillips curve to take account of expected inflation. The first expectations introduced were adaptive expectations:

$$
\dot{W}=f\left(U, \dot{P}^{e}\right)
$$

where $\dot{W}$ is the money wage rate, $U$ the unemployment rate, $\dot{P}^{e}$ the inflation expectations.

Friedman (1977) distinguished three stages of the Phillips curve: first, a stable trade-off between inflation and unemployment; second, the distinction between short and long run: in the long run, the Phillips curve was vertical; third, a positively sloped Phillips curve. Today, the most accepted is the second stage, but the new classical school (see Lucas (1973)) with the introduction of rational expectations and market clearing, admits that the Phillips curve is almost vertical, even in the short run. However, the new Keynesian school do not believe that markets clear all the time, so sticky wages and prices imply that the Phillips curve is not vertical in the short run. ${ }^{1}$

According to Roberts (1995), the New Keynesian Phillips curve is:

$$
\Delta P_{t}-E_{t} \Delta P_{t+1}=c_{0}+\gamma y_{t}+\varepsilon \quad \gamma>0_{t}
$$

where $P_{t}$ is the $\log$ of actual price at time $t, E_{t}$ are the rational expectations at time $t, y_{t}$ is the percent deviation of aggregate output from is trend, $\gamma$ is a positive constant, and $\varepsilon_{t}$ is is a residual error term.

This equation is similar to that of Friedman and Phelps, but the New Keynesian models "emphasize the role of explicit nominal rigidities in interpreting model" (Roberts, 1995, p. 980), this equation is also similar to that of Lucas (1973), except this equation "includes expectations do next period's inflation, whereas Lucas's supply curve incorporates expectations of current inflation. The reason future inflation matters in the New Keynesian model is that prices are sticky." (Roberts, 1995, p. 980).

Remembering the Okun Law we can have the equation:

$$
\Delta P_{t}-E_{t} \Delta P_{t+1}=c_{0}-\eta \Delta U_{t}+\varepsilon_{t} \quad \eta>0
$$

where $\mathrm{U}$ is the unemployment rate.

According to Galí and Gertler (1999) we can have a hybrid version of the New Keynesinan Phillips curve:

$$
\pi_{t}=\delta\left(y-y^{*}\right)+(1-\phi) E_{t} \pi_{t+1}+\phi \pi_{t-1} \quad 0<\phi<1
$$

\footnotetext{
${ }^{1}$ See Ball, Mankiw and Romer (1988) and Roberts (1995).

RE\&D

Econ. e Desenv., Santa Maria, vol. 26, n.2, p. 74 - 84, jul. - dez. 2014
} 
where $\pi_{\mathrm{t}}$ is the inflation rate at time $\mathrm{t}, \mathrm{y}-\mathrm{y}^{*}$ is the output gap. Therefore inflation depends on the output gap, expected future inflation and lagged inflation. But the difficult with using the output gap let the economists to use measures of real marginal cost, and the hybrid Phillips curve becomes: ${ }^{2}$

$$
\pi_{t}=\lambda m c_{t}+\gamma_{f} E_{t} \pi_{t+1}+\gamma_{b} \pi_{t-1}+\varepsilon_{t}
$$

where $m c$ is a measure of aggregate marginal cost. ${ }^{3}$

But remembering the Okun Law we can have the equation:

$$
\pi_{t}=\alpha\left(U-U^{*}\right)+\gamma_{f} E_{t} \pi_{t+1}+\gamma_{b} \pi_{t-1}+\varepsilon_{t}
$$

where $U$ is the unemployment rate. So the inflation rate depends on the unemployment rate, expected future inflation and lagged inflation.

Mazumder (2012) finds "there is evidence to this day that the Phillips Curve remains highly robust between different monetary policy regimes, contrary to the claims of Lucas (1976)" in his study for the United States, so the traditional Phillips curve is alive.

We can say that the three main factors influencing wage negotiation and driving the rate of growth of nominal wages are core inflation, productivity growth and the state of demand in the labour market. The core or underlying rate of inflation has one backward-looking component and one forward-looking component, but in low-inflation periods there is little difference between core and actual inflation. In our model, we can refer to it as expectation of inflation. The productivity gains means that wages can rise without any increase in unit labour cost, so without impact on the inflation rate. In our model, we can expect a positive impact of productivity growth on wages. The state of demand in the labour market can be measured by the unemployment rate. When the unemployment rate is above the equilibrium rate of unemployment (NAIRU in economic terms), wages tend to slow down, and vice-versa. In our model, we can expect a negative relationship between the rate of growth of nominal wages and the unemployment rate, where $\dot{Q}$ is the average labour productivity growth:

$$
\dot{W}=f\left(\stackrel{(-)}{U}, \stackrel{(+)}{P}^{e}, \stackrel{(+)}{\dot{Q}}\right)
$$

\section{Data}

We use annual data whose justification in theoretical terms is given by Campbell and Perron (1991, p. 153), where either due stationarity analysis needs a long-term period, or because "seasonal adjustment procedures often create a bias toward nonrejection of a unit root hypothesis" (Campbell and Perron, 1991, p. 153). As stated previously, we formulated the model on the basis of rates of change, so we opted to transform the available annual data into rates of change. Thus we selected four annual variables for the period 1961-2012: $\dot{W}$, money wages rate; $\dot{P}$, inflation rate; $U$, unemployment rate $\dot{Q}$, average labour productivity growth.

The data source is AMECO.

\footnotetext{
${ }^{2}$ See Andreas Hornstein (2008).

3 See also Russel and Chowdhury (2013) about "modern" theories of the Phillips curve and Nason and Smith (2008) about the application of the New Keynesian Phillips curve to the USA.
} 


\section{Stationarity of the data}

The Dickey-Pantula (1987) test allows us to reject the null hypothesis of I(2) against I(1) in all variables studied. With the $\mathrm{ADF}$ test, we can say the variables $\dot{W}, U, \dot{P}$ are $\mathrm{I}(1)$, and the variable $\dot{Q}$ is $\mathrm{I}(0)$. Using the Perron and Vogelsang (1992) test to inquire for a unit root in times series under structural change with endogenous choice of the break point $(\mathrm{Tb})$, with the procedure of endogenous selection of k described by Perron (1997, p. 359), we can reach the same conclusion.

\section{Estimation of the Phillips curve model}

We use the Johansen method as being the one that allows the detection of the presence of more than one cointegrating vector among variables in the study.

There are stationary regressors in the VAR model, so we cannot use the critical values of Johansen (1996). Therefore, we follow the methodology of Rahbek and Mosconi(1999), which consists of adding to the VAR the cumulated explanatory $\mathrm{I}(0)$ variables as $\mathrm{I}(1)$ exogenous variables, and thus the critical values of the trace or eigenvalue tests of, among other authors, Pesaran, Shin and $\operatorname{Smith}(2000)$ can be used. ${ }^{4}$ First, as we have exogenous variables, the cointegrated VAR model to use corresponds to the conditional model: ${ }^{5}$

$$
\Delta Y_{t}=\mu_{c}+\delta_{c} t+\sum_{i=1}^{k-1} \Psi_{i} \Delta X_{t-i}+\Pi_{y} X_{t-1}+\omega \Delta Z_{t}+\varepsilon_{c t}
$$

where $X_{t}$ is a $N \times 1$ vector of $I(1)$ variables, which we can divide into $N_{y}$ endogenous $I(1)$ variables $\left(Y_{t}\right)$ and $N_{z}$ exogenous $I(1)$ variables $\left(Z_{t}\right)$, such that $N_{y}+N_{z}=N$. $\Pi_{y}$ is the long-run multiplier matrix of order $\left(\mathrm{N}_{\mathrm{y}} \times \mathrm{N}\right)$ given by $\Pi_{\mathrm{y}}=\alpha_{\mathrm{y}} \beta^{\prime}$, where $\alpha_{\mathrm{y}}$ is a $\left(\mathrm{N}_{\mathrm{y}} \times \mathrm{r}\right)$ matrix and $\beta$ a $(\mathrm{N} \times \mathrm{r})$ matrix of $\mathrm{r}$ cointegranting vectors.

The null hypothesis of the cointegration rank (existence of $r$ cointegrating vectors) is written:

$$
\text { Hr: } R\left[\Pi_{\mathrm{y}}\right]=\mathrm{r}, \quad \mathrm{r}=0, \ldots, \mathrm{N}_{\mathrm{y}} \text {; }
$$

where " $R$ " is the rank of the matrix.

In the estimation of the conditional model (8), we can consider 5 cases (or models) consonant with the restrictions imposed on the deterministic terms, in accordance with $\operatorname{PSS}(2000)$.

\subsection{Estimation of the Long-Term Model}

At the beginning we have a model with three endogenous $\mathrm{I}(1)$ variables $(\dot{W}, U, \dot{P})$, and one exogenous $\mathrm{I}(0)$ variable $(\dot{Q})$.

In terms of $\mathrm{k}$ order of the VAR, we selected VAR(3), using either multivaried statistics, or univaried statistics, so that the estimated residuals have no serial correlation (LM test), no

\footnotetext{
${ }^{4}$ Referred to as PSS(2000), afterwards.

${ }^{5}$ We assume that the $Z_{t}$ variables are weakly exogenous and they are not cointegrated between them, which implies that we can efficiently determine and test the parameters of long term ( $\alpha$ and $\beta$ ), but with resource to the conditional model [see PSS(2000)].
} 
autoregressive conditional heteroscedasticity (ARCH test) and they do not deviate too much from normality (BJ test), as Johansen (1996, p. 20) recommends.

With $\mathrm{k}=3$, whatever the model of the Johansen method is in relation to the deterministic terms, we cannot reject the existence of two cointegranting vectors by the Trace test .

We cannot reject the weak exogeneity of the unemployment rate (U) in the models II to $\mathrm{IV}^{6}{ }^{6}$ on a significance level of $5 \%$ (Table 1 ).

Table 1 - Weak exogeneity test ${ }^{7}$ of unemployment rate (U)

\begin{tabular}{|c|c|c|c|}
\hline Model & Model II & Model III & Model IV \\
\hline LR test & $\chi^{2}(2)=0.26[0.88]$ & $\chi^{2}(2)=0.66[0.72]$ & $\chi^{2}(2)=0.11[0.95]$ \\
\hline
\end{tabular}

Note: The null hypothesis is H0: $\alpha_{U}=0$.

Source: Calculations were performed by the author.

We estimated the model with two endogenous $\mathrm{I}(1)$ variables ( $\dot{W}$ and $\dot{P}$ ), one I(1) exogenous variable $(\mathrm{U})$, one $\mathrm{I}(0)$ variable $(\dot{Q})$. in accordance with the Rahbek and Mosconi(1999) methodology:

\section{$\dot{W} \quad \dot{P} ; U \operatorname{csum} \dot{Q} \& \Delta \mathrm{U} \dot{Q}$}

We confirm the k order of the VAR with exogenous $U$, as a $\operatorname{VAR}(3)$ and the methodology of PSS(2000) leads us to choose model IV. Given VAR(3) and model IV, one can confirm that the existence of two cointegranting vectors cannot be rejected, either by the trace test, or by the maximum eigenvalue test (Table 2).

Table 2 - Cointegration tests

\begin{tabular}{|c|c|c|c|c|c|c|}
\hline $\begin{array}{c}\text { Eigenvalue } \\
\lambda\end{array}$ & \multicolumn{3}{|c|}{ Trace test } & \multicolumn{3}{c|}{ Maximum eigenvalue test } \\
\cline { 2 - 7 } & $\mathrm{H} 0$ & $\mathrm{Ha}$ & Trace & $\mathrm{H} 0$ & $\mathrm{Ha}$ & $\lambda \max$ \\
\hline 0.47811 & $\mathrm{r}=0$ & $\mathrm{r} \geq 1$ & $51.3219^{\mathrm{a}}$ & $\mathrm{r}=0$ & $\mathrm{r}=1$ & $31.8642^{\mathrm{a}}$ \\
\hline 0.32773 & $\mathrm{r} \leq 1$ & $\mathrm{r}=2$ & $19.4577^{\mathrm{a}}$ & $\mathrm{r} \leq 1$ & $\mathrm{r}=2$ & $19.4577^{\mathrm{a}}$ \\
\hline
\end{tabular}
a the null hypothesis (H0) is rejected against the alternative hypothesis (Ha).
Source: Calculations were performed by the author.

The AIC, SBC and HQC criterions also select the model with $\mathrm{r}=2$. The vector 1 normalized in relation to $\dot{W}$ without restrictions with $\mathrm{X}^{\prime} \mathrm{t}=\left[\begin{array}{ll}\dot{W} & \dot{P}\end{array}\right.$ csum $\dot{Q}$ Trend $]$ is given by:

$$
\beta_{1}^{\prime}=\left[\begin{array}{lllll}
1 & -0.707 & 1.058 & -0.143 & 0.373
\end{array}\right]
$$

The vector 2 normalized in relation to $\dot{P}$ without restrictions with $\mathrm{X}^{\prime} \mathrm{t}=[\dot{P} \dot{W} U$ csum $\dot{Q}$ Trend] is given by:

$$
\beta_{2}{ }^{\prime}=\left[\begin{array}{lllll}
1 & -0.962 & 0.396 & -0.158 & 0.058
\end{array}\right]
$$

\footnotetext{
${ }^{6}$ PSS(2000) models.

${ }^{7}$ Elabored on CATS in RATS by the restriction $\mathrm{B}^{\prime *}$ alpha $=0$ with $\mathrm{B}^{\prime}=\left[\begin{array}{lll}0 & 1 & 0\end{array}\right]$ selecting $\mathrm{r}=2$ in the model $\dot{W} U \dot{P}$; csum $\dot{Q} \& \dot{Q}, \operatorname{lag} 3$.
} 
so, we have the ecm1 and the ecm2:

$\mathrm{ECM} 1=\dot{W}-0.707 \dot{P}+1.058 U-0.143 \operatorname{csum} \dot{Q}+0.373$ Trend

$\mathrm{ECM} 2=\dot{P}-0.962 \dot{W}+0.396 U-0.158 \operatorname{csum} \dot{Q}+0.058$ Trend

and therefore, the long-term relationships are:

$$
\begin{aligned}
& \dot{W}=0.707 \dot{P}-1.058 U+0.143 \operatorname{csum} \dot{Q}-0.373 \text { Trend } \\
& \dot{P}=0.962 \dot{W}-0.396 U+0.158 \operatorname{csum} \dot{Q}-0.058 \text { Trend }
\end{aligned}
$$

that is, firstly, the wage inflation rate relates positively to the inflation rate, negatively to the unemployment rate and positively to the average labour productivity growth index The Trend means there are others factores the have some influence on wage inflation. Secondly, the inflation rate relates positively to the wage inflation rate, negatively to the unemployment rate and positively to the average labour productivity growth index. The Trend means there are others factores the have some influence on inflation rate.

According Koustas and Serletis (2003) "the evidence is consistent with a vertical long-run Phillips curve for most countries in the sample, with the exception of Italy", so is in accordance of our long-run relationship for Italy. Schreiber and Wolters (2007) finds also "a cointegration relationship between inflation and unemployment " in Germany.

\subsection{Estimation of the Short-Term Model}

The estimation of the multivariate model with only variables introduced initially in VAR(3) allows us to get the results in Table 3.

\begin{tabular}{|c|c|c|}
\hline $\begin{array}{l}\text { Equation/ } \\
\text { Regressor }\end{array}$ & $\Delta \dot{\mathbf{W}}$ & $\Delta \dot{P}$ \\
\hline No. Observations & $\begin{array}{c}T=49 \\
{[64-12]}\end{array}$ & $\begin{array}{c}T=49 \\
{[64-12]}\end{array}$ \\
\hline Intercept & $-2.5461[.558]$ & $-14.0490[.001]$ \\
\hline$\Delta \dot{W}(-1)$ & $-.36032[.233]$ & $-.54006[.061]$ \\
\hline$\Delta \dot{P}(-1)$ & $.46902[.060]$ & $.48843[.038]$ \\
\hline$\Delta U(-1)$ & $1.3617[.087]$ & $.78117[.289]$ \\
\hline$\dot{Q}(-1)$ & $.20231[.342]$ & $.56179[.007]$ \\
\hline$\Delta \dot{W}(-2)$ & $-.22868[.290]$ & $-.26921[.186]$ \\
\hline$\Delta \dot{P}(-2)$ & $.32515[.127]$ & $.24820[.212]$ \\
\hline$\Delta U(-2)$ & $.98682[.160]$ & $-.0059655[.993]$ \\
\hline$\dot{Q}(-2)$ & $.09977[.679]$ & $-.12000[.596]$ \\
\hline ECM1(-1) & $8.4370[.000]$ & $.52461[.791]$ \\
\hline ECM2(-1) & $-6.2350[.005]$ & $-8.2123[.000]$ \\
\hline
\end{tabular}

Table 3 - Multivariate model estimation 


\begin{tabular}{|l|r|r|}
\hline$\Delta \boldsymbol{U}$ & $-1.4917[.012]$ & $-.73138[.177]$ \\
\hline$\dot{\boldsymbol{Q}}$ & $.21961[.365]$ & $.26881[.239]$ \\
\hline \hline$\overline{\mathbf{R}}^{\mathbf{2}}$ & .48428 & .35138 \\
\hline SEE & 2.0913 & 1.9625 \\
\hline $\mathbf{D W}$ & 2.1302 & 2.0467 \\
\hline LM$(\mathbf{1}, \mathbf{3 5})$ & $1.3634[.251]$ & $1.2138[.278]$ \\
\hline RESET(1, 35) & $1.8292[.185]$ & $3.3723[.075]$ \\
\hline BJ(2) & $.21542[.898]$ & $6.1678[.046]$ \\
\hline HET(1, 47) & $.3021 \mathrm{E}-3[.986]$ & $3.4911[.068]$ \\
\hline ARCH(3, 33) & $1.3933[.262]$ & $1.0991[.363]$ \\
\hline
\end{tabular}

Note: see annex about diagnostic tests description and other notes.

Source: Calculations were performed by the author.

The variation of the wage inflation rate relates positively and significantly at $1 \%$ level to the error correction mechanism (ECM1) with an adjustment coefficient of about (8.0) and relates negatively and significantly at $1 \%$ level to the error correction mechanism (ECM2) with an adjustment coefficient of about (-6.0); therefore, there is a significant response to the long-term disequilibria. Besides this adjustment, the wage inflation rate responds positively and significantly to a lagged inflation rate and negatively and significantly to the unemployment rate.

The variation of the inflation rate relates positively and significantly at $1 \%$ to the error correction mechanism (ECM2), with an adjustment coefficient of about (-8.0). It relates positively and significantly at $5 \%$ to lagged variation of inflation rate and to the lagged average labour productivity growth. It presents a negative and but not significant relation to the variation of the unemployment rate.

The diagnostic tests indicate that, in both equations, the residuals are not autocorrelated, are homoescedastics, and the autoregressive conditional heteroescedasticity is also absent until the third order. We cannot reject correct specification of the model.

In both equations, CUSUM and CUSUMSQ tests do not cross any of the significant bars at $5 \%$ level.

With the aim of obtaining a parsimonious Phillips curve model, we tried to remove from the equation of $\Delta \dot{W}$ all the variables not significant at 5\% level, using the Wald test on the joint nullity of its coefficients. We reject the exclusion of these variables from the model with the $\chi^{2}(9)=26.8059[.002]$, so we leave the average labour productivity and we cannot reject the exclusion of eight variables from the model with the $\chi^{2}(8)=12.8718[.116]$, so the parsimonious model is $\Delta \dot{W}=\mathrm{f}\left(\mathrm{inpt},, \Delta \dot{P}_{t-1},, \mathrm{ECM} 1_{\mathrm{t}-1,}, \mathrm{ECM} 2_{\mathrm{t}-1}, \Delta \mathrm{U}, \dot{\boldsymbol{Q}}\right)$. The estimation of the $\Delta \dot{W}$ equation with these regressors (W1 equation - Table I - Annex) presents all the coefficients significant at 5\%, except the intercept and the ECM2(-1), and the diagnostic tests are very good. $\Delta \dot{W}$ is a function of the lagged variation of the inflation rate and of the ECM1 (long-term relationship between $\dot{W}$ and the other variables), and is also function of the variation in unemployment rate and of the average labour productivity growth.

We cannot reject either the predictive capacity after 2005 or the structural stability before and after 2005 (W2 equation). 
In all the estimated equations, we can verify the coefficient stability as the Chow(1960) tests suggest. The coefficient of ECM1 $1_{\mathrm{t}-1}$ is more stable, about 7.0. The coefficient of $\Delta \dot{P}_{t-1}$ varies between 0.3 and 0.37 , the coefficient of $\Delta \mathrm{U}$ varies between -1.3 and -2.7 and the coefficient of $\dot{\boldsymbol{Q}}$ varies between 0.56 and 0,71 .

In all equations of the parsimonious model, CUSUM and CUSUMSQ tests do not cross any of the significant bars at 5\% level. However, not all the residuals are inside the line bands of double-standard deviation. In the period 1964-2012, as we verify that the plot of residuals crosses two standard error bands in 1979.

\section{Conclusion}

In the long term, there are two long-term relationships: the wage inflation rate relates positively to the inflation rate, negatively to the unemployment rate and positively to the average labour productivity growth index, as was expected; the inflation rate relates positively to the wage inflation rate, negatively to the unemployment rate and positively to the average labour productivity growth index, as was expected.

In the short term, the variation of the wage inflation rate relates positively and significantly to the error correction mechanism with wage inflation as dependent variable and negatively to the error correction mechanism with inflation rate as dependent variable, therefore, there is a significant response to the long-term disequilibria. Besides this adjustment, the wage inflation rate responds positively and significantly to a lagged inflation rate and negatively and significantly to the unemployment rate. It relates positively to the average labour productivity and is significant in the parsimonious model. We can have a parsimonious model as a relationship between the wage inflation rate, the lagged inflation rate, the two errors correction mechanisms, the unemployment rate and the average labour productivity growth.

\section{References}

BALL, L.; MANKIW, N. G. ; ROMER, D. The New Keynesian Economics and the OutputInflation Trade-off. Brookings Papers on economic Activity, 1, pp. 1-82, 1998.

CAMPBELL, J. Y.; PERRON, P. Pitfalls and Opportunities: What Macroeconomics Should Know about Unit Roots. NBER Macroeconomics Annual, pp. 141-201, 1991

CHOW, Gregory C. Tests of Equality Between Sets Coefficients in Two Linear Regressions. Econometrica, v. 28, n.3, pp.591-605, 1960.

DICKEY, D. A.; PANTULA, S. G. Determining the Order Differencing in Autoregressive Processes. Journal of Business and Economic Statistics, v. 5, n.4, pp. 455-461, 1987 
FRIEDMAN, M. The Role of Monetary Policy. American Economic Review, v. 58, n.1, pp.1-17, 1968.

FRIEDMAN, M. Nobel Lecture: Inflation and Unemployment. Journal of Political Economy, v. 85, n. 3, pp. 451-472, 1997.

GALÍ, J.; GERTLER, M. Inflation Dynamics: A Strutural Econometric Analysis. Journal of Monetary Economics, v. 44, pp. 195-222, 1999.

HANSEN, H.; JUSELIUS, K. CATS in RATS: Cointegration Analysis of Time Series, Estima, Evanston, Illinois, 1995.

HORNSTEIN, A. Introduction to the New Keynesian Phillips Curve. Economic Quarterly, v. 94, n. 4, pp. 301-309, 2008.

JOHANSEN, S. Likelihood-Based Inference in Cointegration Vector Autoregressive Models. Oxford: Oxford University Press, 1996.

KOUSTAS, Z.; SERLETIS, A. Long-run Phillips-type Trade-offs in European Union Countries. Economic Modelling, v. 20, pp. 679-701, 2003.

LIPSEY, R. G. The Relation between Unemployment and the Rate of Change of Money Wage Rates in the United Kingdom, 1862-1957: A Further Analysis. Economica, v. 27 n.105, pp. 1-31, 1960.

LUCAS, R. E., Jr. Some International Evidence on Output-Inflation Tradeoffs. American Economic Review, v. 63, n. 3, pp. 326-34, 1973.

LUCAS, R. E., Jr. Econometric Policy Evaluation: A Critique. Carnegie-Rochester Conference Series on Public Policy, v.1, pp.19-46, 1976.

MAZUMDER, S. The Volcker-Greenspan-Bernanke Phillips Curve. Applied Economics Letters, v. 19, pp. 387-391, 2012.

NASON, J. M.; and SMITH, G. W. The New Keynesian Phillips Curve: Lessons From Single-Equation Econometric Estimation. Economic Quarterly, v. 94, n. 4, pp. 361-395, 2008 .

PERRON, P.; VOGELSANG, T. J. Nonstationarity and Level Shifts with an Application to Purchasing Power Parity. Journal fo Business and Economic Statistics, v. 10, n. 3, pp. 301-320, 1992.

PERRON, P. Further Evidence on Breaking Trend Functions in Macroeconomic Variables. Journal of Econometrics, v. 80, n. 2, pp. 355-385, 1997.

PESARAN, M. H.; SHIN, Y.; SMITH, R. J. Structural Analysis of Vector Error Correction Models with Exogenous I(1) Variables. Journal of Econometrics, v. 97, n. 2, pp. 293$343,2000$.

PHELPS, E. S. Phillips Curves, Expectations of Inflation and Optimal Unemployment Over Time. Economica, v. 34, pp. 254-81, 1967. 
PHILLIPS, A. W. The Relation Between Unemployment and the Rate of Change of Money Wage Rates in the United Kingdom, 1861 - 1957. Economica, v. 25, n. 100, pp. 283-299, 1958.

RAHBEK, A.; MOSCONI, R. Cointegration Rank Inference with Stationary Regressors in VAR Models. Econometrics Journal, v. 2, pp. 76-91, 1999.

ROBERTS, J. M. New-Keynesian Economics and the Phillips Curve. Journal of Money, credit and Banking v. 27, n. 4, pp. 975-984, 1995

RUSSEL, B.; CHOWDHURY, R. A. Estimating United States Phillips curves with expectations consistent with the statistical process of inflation. Journal of Macroeconomics, v. 35, pp. 24-38, 2013.

SAMUELSON, P.; SOLOW, R. Problem of Achieving and Maintaining a Stable Price Level: Analytical Aspects of Anti-Inflation Policy. American Economic Review, v. 50, n. 2, pp. 177-194, 1960.

SCHREIBER, S.; WOLTERS, J. The long-run Phillips curve revisited: Is the NAIRU framework data consistent?. Journal of Macroeconomics, v. 29, pp. 355-367, 2007. 
ANNEX

Table I: Parsimonious Equations of $\Delta \dot{W}$

\begin{tabular}{|c|c|c|}
\hline \multirow{2}{*}{$\begin{array}{l}\text { Equation/ } \\
\text { Regressor }\end{array}$} & W1 & $\mathbf{W 2}$ \\
\hline & $\begin{array}{c}T=49 \\
{[64-12]}\end{array}$ & $\begin{array}{l}T_{1}=43, T_{2}=7 \\
{[64-05]}\end{array}$ \\
\hline Intercept & 3.6034[.157] & $3.0251[.218]$ \\
\hline$\Delta \dot{P}_{(-1)}$ & $.36895[014]$ & $.30929[032]$ \\
\hline ECM1(-1) & $6.8753[.000]$ & $7.3182[.000]$ \\
\hline ECM2(-1) & $-2.1568[.172]$ & $-2.6352[.099]$ \\
\hline$\Delta \mathbf{U}$ & $-1.2757[.024]$ & $-2.7176[.000]$ \\
\hline$\dot{Q}$ & $.55588[.004]$ & $.70769[.001]$ \\
\hline$\overline{\bar{R}^{2}}$ & .39361 & (.53150 \\
\hline SEE & 2.3609 & 2.2164 \\
\hline DW & 1.9813 & 1.9468 \\
\hline $\mathbf{L M}(1$, T-k-1) & $1.0019[.322]$ & $.014913[.903]$ \\
\hline $\operatorname{RESET}_{(1, T-k-1)}$ & $.41720[.522]$ & $.10152[.752]$ \\
\hline BJ(2) & 1.0458[.593] & $.38770[.824]$ \\
\hline $\operatorname{Het}(1, T-2)$ & $3.3943[.072]$ & $.16355[.688]$ \\
\hline $\operatorname{ARCH}(3, T-k-3)$ & $.892701[.453]$ & $2.4166[.083]$ \\
\hline $\operatorname{Chow}\left(\mathbf{T}_{2}, \mathbf{T}_{1}-\mathrm{k}\right)$ & & $1.8464[.107]$ \\
\hline $\operatorname{Cov}\left(k, T_{1}+T_{2}-2 k\right)$ & & $2.1293[.072]$ \\
\hline
\end{tabular}

Notes: Dependent Variable: $\Delta \dot{W}$; Estimation Method: OLS; ECM1 $=\dot{W}-0.707 \dot{P}+1.058 U-0.143$ csum $\dot{Q}+0.373$ Trend e ECM2 $=\dot{P}-0.962 \dot{W}+0.396 U-0.158$ csum $\dot{Q}+0.058$ Trend estimated on the model: $\dot{W} \dot{P} ; U$ csum $\dot{Q} \& \Delta U \dot{Q}$.

Between square brackets: p-value or sample period (on the top). On the estimated coefficients, the null hypothesis is $\mathrm{H} 0$ : $\beta=0$, and the Student $t$ test is used.

$\mathbf{T}=$ number of observations used in regression; $\mathbf{k}=$ number of estimated coefficients; $\mathbf{T}_{\mathbf{1}}=$ sub-sample used in estimation; $\mathbf{T}_{\mathbf{2}}=$ Period post-sample (forecasting test) or second sub-sample (stability test, only possible when $\mathrm{T}_{1}>\mathrm{k}$ and $\mathrm{T}_{2}>\mathrm{k}$ ).

Source: Calculations were performed by the author.

\section{Diagnostic tests description:}

LM - statistic of Lagrange Multiplier test for serially correlated residuals ;

RESET - statistic of Ramsey)'s RESET test of functional form misspecification;

BJ - statistic of Jarque-Bera's test of normality of regression residuals;

HET - statistic of Heteroscedasticity test ;

ARCH - statistic of Autoregressive Conditional Heteroscedasticity test;

Chow-statistic of Predictive failure test ( $2^{\text {nd }}$ test of Chow(1960));

$\operatorname{Cov}$ - statistic of Chow's test of stability of regression coefficients $\left(1^{\text {st }}\right.$ test of Chow(1960)). 